\title{
The History of Celtic Scholarship in Russia AND THE SOVIET UNION
}

\author{
SÉAmus Mac MathúNA
}

\begin{abstract}
Mr Chairman, Colleagues, Ladies and Gentlemen, let me begin by thanking our distinguished Patron, Professor Karl Horst Schmidt, for agreeing to open this inaugural conference of Societas Celto-Slavica. We are greatly honoured by his presence here today and we thank him most sincerely for his excellent introduction and kind words regarding the formation of the Society.
\end{abstract}

\section{Introduction}

I thought initially it would be possible in my lecture this morning to give a brief outline of the main works and achievements of Celtic scholarship in the Slavic countries, secure in the knowledge that it would not be necessary to discuss Celtic Studies in Poland as this subject would be dealt with by Professor Piotr Stalmaszczyk in a subsequent paper. ${ }^{1}$ However, having gathered together a significant amount of material on Celtic Studies in various countries - Russia, Czechia, ${ }^{2}$ Bulgaria, ${ }^{3}$ Serbia, ${ }^{4}$ Croatia, ${ }^{5}$ and others - I realised that I could not do the subject justice in the time available

\footnotetext{
I wish to thank my colleague, Dr. Maxim Fomin, for his assistance in the preparation of this paper.

2 Czechia has a long tradition of scholarship relating to Celtic Studies. One of the many influential Irish colleges established on the Continent of Europe, which made important contributions to Irish heritage and scholarship, was located in Prague in the seventeenth and eighteenth centuries (http://www.irishineurope.com). There have also been many fine Czech linguistic and archaeological scholars. See, for example, the works of the talented Celtic scholar, Josef Baudiš (a bibliography of whose works was compiled by Václav Machek in 1948, available online at http://www.volny.cz/enelen/baud/baud bib.htm), and other eminent scholars, such as the archaeologists Jan Filip (1956, 1961) and Natalie Venclová (1995, 1998, 2000, 2001), and linguists, such as Václav Machek (1963), Václav Blažek (1999, 2001, 2001a, 2003), and Vera Čapková $(1987,1997)$. The work of the Centre for Irish Studies in Charles University (Prague) should also be mentioned. Opened in 2002, it offers courses in Irish and has published a bibliography of many works concerning Irish and Celtic scholarship, available at http://uaa. ff.cuni.cz/ibibliography/index.htm.

3 See the works of the archaeologist Nicola Theodossiev (2000, 2005). On the work of Ivan Duridanov (1997) with regard to Celtic settlement in the Balkans, see below.

4 See Borislav Jovanović (1984, 1988, 1992), Petar Popović (1977, 1991, 1998 (with M. Vukmanović)) and Jovan Todorović (1974, 1980).

5 See the works of the archaeologist Nives Majnarić-Pandžić (1970, 1984), and of the linguist Ranko Matasović (2003, 2003a, 2004).
} 
without considerably narrowing the scope of my investigations: I decided therefore to confine myself primarily to Celtic Studies in Russia and the former Soviet Union. ${ }^{6}$ The history of Celtic scholarship in other Slavic countries will, I hope, be addressed on another occasion.

\section{The Slavs and the Celts}

Of all the ethnic European peoples, the Slavs are the most numerous. They reside principally in Eastern Europe, but are also found in Asia. The Slavic languages are normally divided into three main groups, as follows: East Slavic (of which the major sub-groups are Russian, Ukrainian, and Byelorussian); West Slavic (including Lekhitic, that is, Polish and related divisions, Czech-Slovak, and Sorbian); and South Slavic (with two main divisions, namely, Bulgarian-Macedonian, and Serbo-Croatian-Slovene). While the eastern origin of Slavic is not in doubt, the assumption of an original Balto-Slavic unity still remains uncertain. As Professor Schmidt has pointed out in his address, the many correspondences between the languages may be due to a common IE inheritance or to shared forms which have resulted from having been in close proximity for an extended period of time. Moreover, the Baltic area at the beginning of the historical era was larger than it is today, much of it being later slavicised (Schmid 1976: 15). Several centuries before Christ, the proto-Slavic dialect area appears to be between the Rivers Oder and Vistula in Poland and the Dnieper in the Ukraine, north of the Carpathian Mountains. This protodialect area is in a kind of so-called intermediate zone. It includes the Illyrian, Thracian and Phrygian languages of the Balkans, and is bordered to the West by Germanic, Celtic and Italic, and to the East by Scythian and Tocharian.

As to some of the other surrounding peoples, the Thracians were located in Thrace which was bordered to the North by the Danubian province of Moesia and to the South by Macedonia; Thrace and Moesia occupy the territory which roughly corresponds to modern Bulgaria. The Phrygians had come from Asia via the south Russian steppes and settled in the Balkans, in proximity to the Thracians and the Illyrians; and between c. 700 BC and 200 BC, the Scythians had settled between the Dnieper and

\footnotetext{
This subject has been previously addressed to some degree by Russian Celtic scholars but has received much less attention from Celticists outside Russia. See Yartseva (1974: 130) and Falileyev 1990-91.
} 
the river Don in the present-day Ukraine. Then, in the historical period, there occurred the great migration of Slavs into Bohemia, Moravia, Austria, the Pannonian plain and, in the fourth century, into the Balkans, and northward along the upper Dnieper river and the Black Sea.

The Celts appear in central Europe along the upper Danube c. 600 BC and spread thereafter to the West, East and South. In the middle of the first millennium, Celtic tribes settled along the upper Oder, thus triggering about the fourth century B.C. a new period of Celto-Slavic contacts in the Carpathians and Silesia. Archaeological evidence, such as the Podkloshevy grave culture of the middle and upper Vistula and the Oder, shows clear Celtic influences (Sedov 1998, 2002). Germanic tribes, who occupied territory adjacent to, and north of the Celts, settled on the lower Oder and Vistula. The Celts also spread into Bohemia, Pannonia, northern Italy and the Balkans. They founded, for example, at the mouth of the Save in Moesia, the town of Singidunum, known today as Belgrade. In 280 BC they invaded Macedonia and crossed thereafter into Asia, settling in Galatia. Hence, the Celts were in close contact with a number of peoples in this zone, including the Slavs.

Using linguistic and archaeological evidence, the problem of the homeland and migrations of the speakers of Proto-Slavic has been discussed by various scholars of the Slavic languages. ${ }^{7}$ And although it is difficult to determine the exact nature of the influence of one language on another in the Proto-Slavic period due to a variety of factors, such as the heterogeneous linguistic situation, a number of Slavic scholars have also taken an interest in this matter and have contributed to the question of contacts between Celtic and Slavic at this time.

For example, in the writings of classical authors - Ptolemy, Pliny and Strabo - there is mention of a people called the Venedes/Veneti or Wenden, who have been identified by many commentators as Slavs (Gołąb 1975: $321 \mathrm{ff}$.), and by others, such as A. A. Shakhmatov (1864-1920) in 1911, as Celts. Shakhmatov's article ' $\mathrm{Zu}$ den ältesten slavisch-keltischen Beziehungen' (1911) is a landmark publication on the question of connections between Celtic and Proto-Slavic in which the author argues, on the basis of toponymic data, that there were indeed early contacts between these two peoples.

See, for example, T. Lehr-Spławiński (1946), Z. Gołąb (1992), V. V. Sedov (1998). 
Shakhmatov was a famous academician, linguist, philologist and historian of ancient cultures. From Serbia originally, he studied in Moscow under the Indo-Europeanist Filipp Fjodorowich (1848-1914), a scholar who had studied in Germany, France and England. Shakhmatov also worked closely with Jan Baudouin de Courtenay, the great linguistic scholar and founder of the Kasaner Linguistic School. His 1911 article referred to here is one of the earliest Celtic contributions by a Slavic scholar on Celtic linguistic matters of this kind. As pointed out by Professor Schmidt, however, Shakhmatov's specific conjectures in this work have not been supported by subsequent investigators such as K. Buga (1924), V. N. Toporov - O. N. Trubachov (1962), and M. Vasmer (1953, 1971).

Further work on Celto-Slavic contact phenomena has been carried out by other Russian scholars including V. A. Dybo (1961); S. B. Bernstein (1961); O. N. Trubachov (1967, 1983); V. V. Martynov (1983); V. P. Kalygin (1997, 2003); A. Falileyev (1997-98, 1999, 2001); ${ }^{8}$ V. V. Sedov $(1998,2002)$, and others, some of whom are mentioned later in this paper. Polish scholars who have contributed to early Celto-Slavic contact matters on linguistic, historical and toponymic

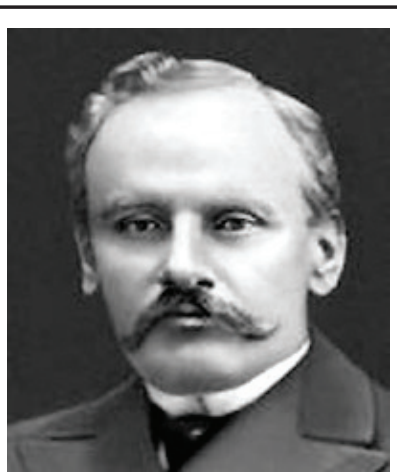

A. A. Shakhmatov (1864-1920) subjects include J. M. Rozwadowski (1897), M. Rudnicki (1936), T. LehrSpławiński (1956a, 1956b), T. Milewski (1961), J. Kuryłowicz (1961a), Z. Gołąb (1972), and P. Stalmaszczyk \& K. Witczak (1995, 2001, 2002). ${ }^{9}$ The work of the Czech scholars J. Filip (1956) and V. Machek (1963) should also be mentioned in relation to early Celto-Slavic contacts. ${ }^{10}$

A. D. Machinsky (1974) has examined various kinds of evidence written, archaeological and toponymic - for the penetration of Celtic tribes into the region east of the Carpathians and north of the Lower Danube. Others who have contributed to the question of early Celtic settlement in the Balkans include V. Beševliev (1967), M. A. Tikhanova (1974), M. V.

\footnotetext{
8 See also Falileyev \& Isaac $(1998,2003)$ and Professor Tristram's discussion of their work in this volume.

9 See Professor Stalmaszczyk's paper in this volume.

${ }^{10}$ Václav Blažek (1995) has discussed Václav Machek’s work. See also his contribution to this volume.
} 
Schukin (1974), Y. B. Tsirkin (1974), O. H. Frey \& M. Szabó (1991) and I. Duridanov (1997). ${ }^{11}$

Some scholars, such as Trubachov, have assumed that the centum stratum in the Slavic languages points to Celtic influence. Recent work by Piotr Stalmaszczyk and Krzysztof Witczak (1995), however, calls this hypothesis into question. They point out that spirantisation of dorso-palatal consonants was not without exceptions and that other centum languages, such as Tocharian dialects, Italic (especially Venetic) and Illyrian, could have influenced Proto-Slavic. On the other hand, they point to a loss of labial $* p$ in conjunction with the depalatalisation of IE $* k$ in three Slavic words as strongly suggesting Celtic influence despite the fact that linguists had not previously "been able to identify even a single Proto-Slavic word whose origin could be definitely ascribed to Celtic influence"(Stalmaszczyk \& Witczak 1995: 225).

The majority of correspondences between Celtic and Slavic are clearly due to a common IE inheritance. The work of Karl Horst Schmidt, Viktor Kalygin, Patrizia de Bernardo Stempel, and Alexander Falileyev suggests, however, that a number of shared features between the language groups have developed at different chronological periods, some as a result of later language contact. In a seminal paper on the subject in 1985, and in further work in 1992 and 1996, Professor Schmidt - one of the few Western Celtic scholars to have made a significant contribution to this area - adduced three items of linguistic evidence which suggest that there were contacts between Celtic and Slavic tribes in the earliest period. The features in question are: the future in $*_{- \text {sye- }} *_{- \text {syo-; }}$ the desiderative formation; and the inflected relative pronoun *yos. These items are not instanced in Italic, which suggests perhaps that there were not close contacts between the Celtic and Italic peoples at that time. These matters are discussed both by Professor Schmidt himself and by Professor Kalygin in the present volume. ${ }^{12}$

Kalygin (2003), Falileyev (1997-98, 1999, 2001), and Falileyev and G. R. Isaac (2003) have contributed a number of further lexical studies supporting this viewpoint. These studies also suggest that some of the shared lexical items, such as the words for 'leek, onion, garlic' - which are taken to be derived from the IE *kes- 'scrape, comb, peel' - may be the

\footnotetext{
See also the references below to Falileyev's work on this subject and also his article in the present volume.

12 See also Pokorny 1936
} 
result of shared innovation during a period of cultural contact between Celts and Slavs before the expansion of Germanic, while others need to be accounted for in other ways. In addition, Falileyev has examined topographical data in Ptolemy's Geography which suggest that Slavic names are typologically closer to Celtic and Daco-Thracian than to Baltic and Germanic. "This", he suggests, "offers clues to the early historical contact zones between the relevant peoples" (Falileyev 2002a: 83). ${ }^{13}$

In this regard it should be noted that Heinrich Wagner took the view that the central position of Celtic within the IE dialects of the first millennium $\mathrm{BC}$ is reflected in numerous isoglosses running between Celtic, Italian and Germanic; Celtic and Balto-Slavic; Celtic and Albanian; and even between Celtic and ancient Greek. From the point of view of linguistic geography, he believed that the earliest home of the Celts must be sought in an area west of the Thracians in modern Hungary and adjacent regions. From here they would have spread to the whole of Western Europe (Wagner 1969: 208-9, 227; repr. in Wagner 1971).

\section{Introduction of Celtic Studies in the Soviet Union}

While early work on Celto-Slavic contacts had a critically important impact on the development of Celtic Studies in Russia, other factors have also played a role. The translation into Russian of Die keltische Zivilisation und ihr Erbe (1961), ${ }^{14}$ the work of the eminent Czech archaeologist Jan Filip, for example, had the effect of stimulating some young scholars to find out more about the Celtic languages, as did the works of Irish authors writing in English. ${ }^{15}$ Nevertheless, the credit for introducing the discipline of Celtic Studies into the Soviet Union must go to A. A. Smirnov (18831962). Born in Moscow, he graduated from the Historical-Philological Faculty of St. Petersburg University in 1907.

Following his Masters, he was appointed in 1911 Privat-Docent at the Department of Romance and Germanic Philology. He went to France on a two-year research trip where he studied under the distinguished Celticist and Indo-Europeanist Joseph Vendryes. During this period (1911-13), he also acted as Secretary of the Editorial Board of Revue Celtique. Smirnov also

\footnotetext{
13 See also R. Ködderitzsch 1993.

${ }^{14}$ Филип, Я. Кельтская циивилизация и ее наследие. Пер. с чеш. Л.П. Можанской и Е.В. Тарабрина. Прага: Изд-во Чехосл. акад. наук: Артия, 1961.

${ }_{15}$ Professor Tatyana Mikhailova (personal communication).
} 


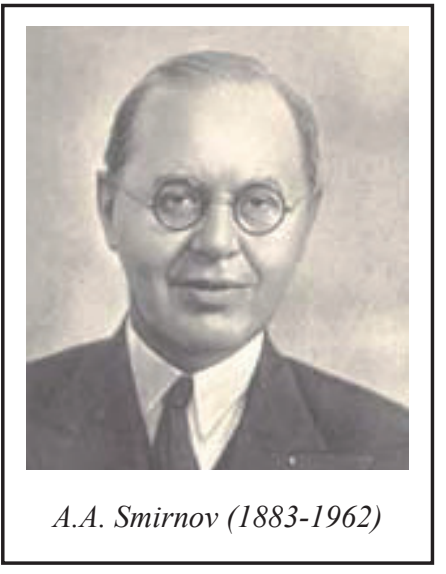

spent some time in Spain, and in Ireland, and attended lectures at the National University of Ireland in Dublin. He taught at St. Petersburg/Petrograd/Leningrad University from 1913 until 1958. His courses included 'An Introduction to Celtic Philology' and 'Celtic Literatures', and his lectures were published as part of the University's 1947 (2nd ed. 1959) coursebook Istoriya zapadnoevropejskoj literatury. Ranneye srednevekov'ye i Vozrozhdeniye (The History of Western European Literature. Early Medieval Ages and Renaissance). His work on Celtic includes an edition of the Medieval Irish tale Aided Muirchertach meic Erca (1915), translations of Irish sagas, Irlandskiye Sagi (1929), and a Russian translation of Lewis and Pedersen's influential book, A Concise Comparative Celtic Grammar (1954), ${ }^{16}$ a formidable undertaking which demanded great stamina.

His Irish Sagas has stood the test of time, going into three editions, in 1929, 1933 and 1961; it was also republished, along with Icelandic sagas, in the 1974 World Library of Literature, a milestone of Russian scholarship which brings together in a unified series major works of the world's literatures from the earliest times to the present. ${ }^{17}$ Tatyana Mikhailova (2004) has recently republished two of Smirnov's translations of Irish sagas in Sagi ob uladakh, namely, Compert Con Culainn and Serglige Con Culainn. Smirnov also published a number of other works in academic journals on Arthurian literature, links between Medieval Breton and Early French literature, and other Celtic matters (Smirnov 1912, 1913, 1914). After his death, one of the most distinguished Russian academicians, V. M. Zhirmunsky, published a bibliography of Smirnov's works (Zhirmunsky 1963).

Viktoriya Nikolayevna Yartseva continued the work of Smirnov at Leningrad and, during a long and highly distinguished academic career, was responsible for the further promotion of Celtic Studies in Russia and

\footnotetext{
16 Льюис Г., Педерсен, Х. Краткая грамматика кельтских языков. Москва: Иностранная литература, 1954.

${ }^{17}$ Smirnov also contributed to Arbois de Jubainville's 1912's translation of Táin Bó Cúalnge, see Best, 1942: 78, item 1155 .
} 
the USSR. Having taken her doctorate in Leningrad in 1940 on 'Razvitiye anglijskogo glagola' ('The Development of the English Verb'), she was appointed to a Lectureship in the Department of Germanic Languages and was simultaneously Leading Research Fellow at the Institute for Linguistics, Moscow. She travelled back and forth between the two cities a couple of times a week for many years. At a later stage in her career she moved to Moscow State University to assume the Directorship of the Department of Germanic Studies ${ }^{18}$ and the Headship of the Institute of Linguistics at the Academy of Sciences. On the basis of her outstanding contribution to scholarship in the USSR, she was elected Corresponding Member of the USSR Academy of Sciences, Moscow.

While Professor Yartseva shared Smirnov's interest in literary matters up to a point, she concentrated primarily on aspects of comparative and typological linguistics and on the history of the Germanic and Celtic languages. Among her works on Celtic are 'Drevneirlandskij i drugiye kel'tskiye yazyki v sisteme indo-evropejskikh yazykov' ('Old Irish and other Celtic Languages in the System of the IE Languages' = Yartseva 1940) and 'Syntaksis infinitiva v drevneirlandskom' ('The Syntax of the Infinitive in Old Irish' = Yartseva 1941), the first two scholarly papers published in the USSR which were dedicated to Celtic linguistic matters.

Professor Yartseva was responsible for initiating the publication into Russian of Smirnov's translation of Lewis and Pedersen, to which she contributed an introduction and commentary. She also edited the Proceedings of the Symposium on the state of Celtic Studies in the Soviet Union which was held in Leningrad in 1974 and which contains articles by most of the practising Celticists of the day (Yartseva 1974). She also initiated the series of Leningrad/St. Petersburg colloquia entitled Yazyk $i$ kul'tura kel'tov (Celtic Languages and Culture), the first of which was held in 1988 and the proceedings of which she herself edited. The series has been held on a regular basis in Leningrad/St. Petersburg since the early 1990s and amply demonstrates the vitality and growing importance of modern and contemporary Russian Celtic scholarship. Much praise must go to Dr. Alexander Falileyev, who succeeded Yartseva in organising

\footnotetext{
18 Thanks to the efforts of Professor Tatyana Mikhailova and others, and in recognition of the advances of Celtic scholarship, the Department now combines both the Germanic and Celtic languages.
} 
the colloquia and editing the proceedings. ${ }^{19} \mathrm{~A}$ memorial volume in honour of Professor Yartseva, to which a number of Russian Celticists contributed, was recently published (Babenko 2000).

\section{Russian Celtic Studies: Linguistics}

Both A. A. Korolyov and I. V. Kryukova contributed linguistic articles to the 1974 Leningrad Symposium.

Dr I. V. Kryukova, a member of the Institute of Linguistics at the Russian Academy of Sciences, also produced an important monograph on verbal change in the Irish language, Glagol'noye slovoizmeneniye $v$ irlandskom yazyke (Verbal Inflection in Irish = Kryukova 1987). Dr A. Falileyev (1990-91: 58) gives the following succinct description of the work:

The aim of Dr. Kryukova's investigations is to provide a systematic analysis of the evolution of verbal inflection from Old to Modern Irish with special regard to dialect data. Several frequent irregular verbs were chosen to be analysed in terms of the inflection of Present, Future and Preterite forms. The author provides a typological interpretation of their evolution. Dr Kryukova marks archaic areas and innovative ones according to the data of the modern Irish dialects. A table of irregular verbal forms in different dialect zones is given as an appendix.

More recently, Dr Kryukova has published a work (Kryukova 1995) on Irish/English language interference and contact phenomena.

Korolyov (1946-1999) studied under Yartseva and in 1973 received his doctorate for a thesis on 'Istoriya form mnozhestvennogo chisla imyon suschestvitel'nykh $\mathrm{v}$ irlandskom yazyke' ('History of the Forms of the Plural Number of Nouns in the Irish Language'). This was, to my knowledge, the first doctoral thesis in Russia on a subject which was devoted entirely to a Celtic topic. He published extensively various philological and linguistic papers on Old Irish, Scottish Gaelic and other Celtic languages (see Korolyov 1971, 1972, 1988), including the first monograph to be published in Russia on a

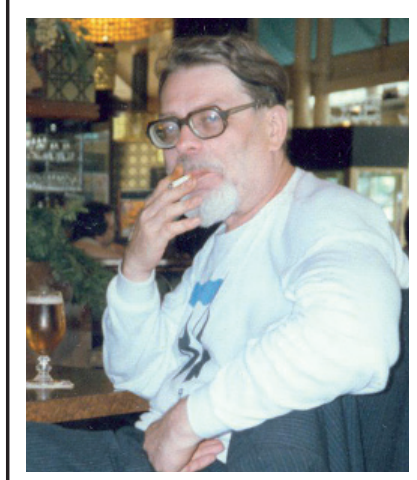

A.A. Korolyov (1946-1999)

\footnotetext{
${ }^{19}$ Other scholars involved in the organisation of the colloquia included V. P. Kalygin, S. V. Shkunayev, N. N. Kazansky, and S. Ivanov.
} 
THE HISTORY OF CELTIC SCHOLARSHIP IN RUSSIA AND THE SOVIET UNION

Celtic subject, Drevnejshiye pamyatniki irlandskogo yazyka (The Oldest Monuments of the Irish Language, 1984). ${ }^{20}$

This work consists of an account of the earliest Irish linguistic forms together with an in-depth analysis and discussion of the Ogam inscriptions, including a Glossary of all lexical items contained in the Ogam corpus. ${ }^{21}$ A. A. Korolyov subsequently became Professor of Comparative Linguistics at the Russian University for the Humanities, specialising in Celtic and Anatolian. He was also affiliated to the Institute of Linguistic Studies at the USSR Academy of Sciences, Moscow.

In some works, Korolyov collaborated with Viktor Pavlovich Kalygin, born in 1950, another important figure in the development of Celtic Studies in Russia, whose untimely death in December of the year 2004 has taken from us one of our most valued Russian colleagues.

He was taught and greatly influenced by various important and farsighted scholars, such as V. N. Yartseva, E. A. Makayev, and L. G. Herzenberg. As holder of an Alexander von Humboldt Foundation scholarship in 1990-92, he also carried out research work in Freiburg i. Breisgau and the Sprachwissenschafliches Institut, Bonn, where he came into close contact with Western Celtic scholars such as Professors Schmidt, Herbert Pilch and Hildegard Tristram.

We should perhaps refer in the first instance to Kalygin and Korolyov's 1989 work Vvedeniye $v$ kel'tskuyu filologiyu (Introduction to Celtic Philology), in which Kalygin demonstrated his wide-ranging knowledge of the Celtic languages and their traditions in his contributions on matters such as the general characteristics of the Celtic languages, the Irish language (including Old Irish, written with Korolyov), Manx, Breton and Cornish. Korolyov also wrote the chapters on the Contintental Celtic languages, Middle and Modern Irish, the language of the Picts, and Welsh in its various stages. The work is intended as an aid to the advanced study of comparative Celtic linguistics and, as the authors point out themselves, they do not seek "to make original contributions too often or put forward viewpoints of their own, but rather to present the problems and summarise

\footnotetext{
${ }^{20}$ See also his contributions to Linguistic Encyclopaedic Dictionary on different matters of Celtic Studies (Korolyov 1990, 1990a, 1990b).

${ }^{21}$ See also his article on the cultural context and background of the Old Irish formula co-cloth ni (Korolyov 1994) and the term fo-naisc, fonaidm 'binds, imposes' (Korolyov 1995). See also the discussion by Dr Fomin in the present volume.
} 


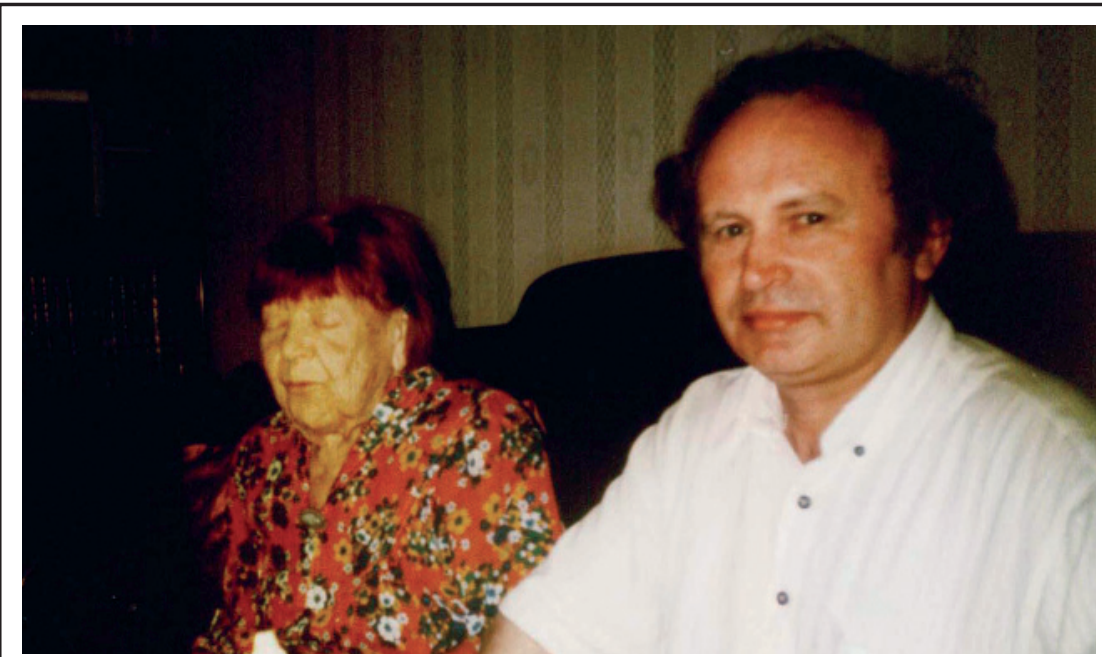

Victoria Yartseva and Viktor Kalygin

Photo taken on the occasion of Yartseva's 90th birthday. November 1996, Moscow (?).

their discussions" (Kalygin \& Korolyov 1989: 3-4). Be that as it may, the assessment of the authors does not do the work justice: it is demonstrably authoritative and quite comprehensive. ${ }^{22}$

Kalygin was a specialist in Early Irish poetics and he demonstrated his grasp of the subject in an important monograph which was originally published in 1986 and republished the year before his death, namely, Yazyk drevnejshej irlandskoj poezii (The Language of the Earliest Irish Poetry, 2003). It is divided into two parts: (a) The Filid and the Earliest Irish Poetic Tradition, and (b) The Languages and Style of the Genealogical Poems. The first part consists of two chapters, one on the functions of the poets and the genres of the earliest poetry, and the other on word-formation and the grammatical features of the poetry. The second part is made up of four chapters and contains a close analysis of archaic Irish genealogical poetry. It has chapters on the nature of Early Irish genealogical poetics, the phonic organisation of the poetic text, lexis and semantics, and syntax. He makes a study of opposition systems, arguing that the distinction between 'poetic' and 'ordinary' language (gnáthbélre: bélre tobaide) corresponds to the distinction between the 'language of gods' and 'the language of men'.

\footnotetext{
22 The second edition of Kalygin \& Korolyov (1989) was published in 2006. It contains a new introduction by Anna Muradova, together with appendices to the chapters of the original edition in which the major works of reference published since 1989 are included.
} 
Kalygin contributed a number of further learned papers on this subject in subsequent years, including an article on the phonic aspects of the material to Professor Tristram's Colloquium on Metrik und Medienwechsel (Kalygin 1991), and a published lecture (Kalygin 1994) in memory of Rudolf Thurneysen, 'Indogermanische Dichtersprache und altirische mythopoetische Tradition'. He also made important contributions to questions relating to the mythological aspects of the Early Irish and Celtic grammatical and onomastic traditions. One can only hope that his body of work will receive in the West the attention it rightly deserves.

Dr Alexander Falileyev studied at the University of Leningrad and subsequently worked there and at the Russian Academy of Sciences. He was an Alexander von Humboldt Foundation scholar at the University of Bonn in 1996-8, where he studied and worked with Professor K. H. Schmidt. He also collaborated with Professor H. L. C. Tristram at the University of Potsdam, and delivered a series of lectures on Early Welsh there in 2003. He was a School of Celtic Studies scholar at the Dublin Institute for Advanced Studies in 1999-2002 (his Walter of Henley. AngloNorman Texts and Welsh Translations will be published later in 2006 by the Dublin Institute for Advanced Studies). He has contributed a range of important etymological studies relating to Celto-Slavic contact phenomena, and has a particular scholarly interest in the linguistic situation in the Balkans and the Ukraine in the early period (see Falileyev 2003-2004, 2004, 2005, 2005a, 2005b, 2005c, 2005d). Based at the Welsh Department of the University of Wales, Aberystwyth, he is presently engaged in a major AHRC research project on Celtic linguistic data from Dacia and Moesia Inferior, having previously been a Research Fellow on the Linguistic Atlas of the Earliest Celtic Place-Names of Europe Project. ${ }^{23} \mathrm{Dr}$ Falileyev has also contributed significant works of scholarship to Early and Medieval Welsh Studies as his recent work Drevnevalijskij Yazyk (The Oldest Welsh Language, Falileyev 2002) demonstrates. This work has been translated into a number of languages, including German and French. $^{24}$

As can be seen up to this point, there is continuity in the Russian linguistic scholarly tradition, from F. Fjodorowich in the last third of the

\footnotetext{
${ }^{23}$ See Sims-Williams 2006.

${ }^{24}$ On the German translation, see Hildegard Tristram's article in this volume.
} 
nineteenth century, through Shakhmatov, Smirnov and Yartseva, to the present day. Fjodorowich trained as an Indo-Europeanist in western Europe and also brought to his work the interests and methodologies of the Slavic tradition. Prior to Fjodorowich, the first reference to the Celtic languages in Russia appears to be in the landmark work by Peter Simon Pallas, commissioned by Catherine II in the late eighteenth century, Linguarum totius orbis vocabularia comparativa, 1787-89 (second edition, 179091). ${ }^{25}$

\section{Russian Celtic Studies: Literature, Poetics and Folklore}

There is an equally important and vital continuity in literary, poetic and folklore scholarship, which requires to be examined in order to appreciate the Slavic philological tradition in general and the background and methods of modern Celtic scholars from the Slavic countries in particular.

Alexander Nikolayevich Veselovsky (1838-1906) is a pivotally important figure in this tradition. Like his contemporary Fjodorowich, he studied in Moscow under I. I. Beslayev, who seems also to have been a figure of great influence.

On completing his studies in Moscow, he went to Spain, where he spent about a year, and then proceeded to Germany and Italy and studied at various universities in these countries, taking courses in Romance and Germanic philology.

He developed an interest in mythology and folk epic and the evolution and genesis of literature, including the conception and origin of poetry. In his 'Comparative Mythology and its Method' (= 'Sravnitel'naya mifologiya i eyo metod', (1873)) Veselovsky carried out a comparative examination of oral and written legends of different literatures. His work on Historical Poetics (= Istoricheskaya poetika, (1940)) was concerned with establishing a methodology for determining genres from original unity, of how the song emerged from ritual, and the transition from collective

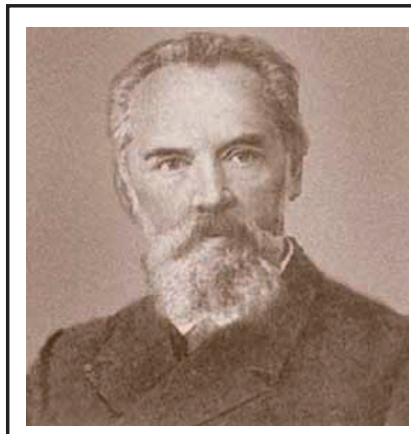

A.N. Veselovsky (1838-1906) to personal creativity.

\footnotetext{
${ }^{25}$ See A. Muradova's article in this volume.
} 
This led him to an elucidation of 'The Poetics of the Subject' ('Poetika syuzhetov') in a series of lectures entitled 'Istoriya poeticheskikh syuzhetov' ('History of poetical subjects') delivered between 1897 and 1906, and published after his death in 1913 (Veselovsky 1913); in these lectures he examined the formal properties of the subject by demonstrating that it could be broken down into structural units and a complex of motifs; he argued further that motifs were primary and themes secondary. Veselovsky was well ahead of his time and it was to take two generations for literary scholarship to catch up with him.

During the course of his investigations, Veselovsky examined the early Irish poetic system and tradition, comparing the various categories of literati with those of other Indo-European traditions and generally demonstrating an acute awareness of the essential nature of Irish poetics. Indeed, the importance of this work for Early Irish poetics was virtually unknown to Western Celtic scholars and has never been fully appreciated. I refer here not to his exposition of the nature and function of the druid, the fili, and the bard, but rather to his analysis of how song and legend, and their stylistics, became not only the object of memory but also the object of science and learning when they became part of the school curriculum during the early Christian period.

Veselovsky made a number of further important observations. Firstly, that the appropriate conditions for the development of the martial epic, which are delayed in the Germanic tradition, are found in the early Irish tradition. ${ }^{26} \mathrm{He}$ demonstrated, with penetrating perspicuity, that early Irish culture was characterised by two major factors: the vitality of the warrior's everyday life in early Ireland on the one hand, and the literary and educational basis of Irish culture, forged from an amalgam of the dynamic native oral tradition preserved by a mandarin class of culture-bearers and power brokers and the Classical and Christian traditions that were brought into the country with the advent of Christianity, on the other. The combination of these factors marks Ireland out as the place in which the first classical Renaissance in Europe took place. One witnesses the birth of consciously developed science and learning and the understanding that

\footnotetext{
${ }^{26}$ See also the early work of N. P. Dashkevich (1886) on parallels between early Celtic epic and the bylinas of Kiev Rus.
} 
the power of the word is acquired by art and labour, one of the first steps towards an appreciation of the act of singing as a personal poetic.

Veselovsky's insights were further developed by Vladimir Propp in his seminal work Morfologiya skazki (Morphology of the Folktale = Propp 1928), which, unfortunately, was not translated into English until 1958. This work has had an enormous impact on a variety of subject areas and led to the application of structural analyses to a range of folklore genres. It did not receive much attention in the Soviet Union because of the formalistic nature of the work which was viewed with deep suspicion by the authorities. Essentially, Propp went beyond both the Finnish School and Veselovsky in demonstrating that the division of tales into categories or types was insufficient and not entirely successful, that the motif was not in itself an indivisible unit, and that structural unity was based on the functional properties of the dramatis personae.

From the sixties onwards, semiotics began to play an increasingly important role in both the West and the East and, in the Soviet Union, the works of scholars, based principally in Moscow and in Tartu in Estonia, such as Y. M. Lotman (1990), V. V. Ivanov (1964), V. N. Toporov (1973, 1995), A. Y. Gurevich (1972) and others influenced significantly Celtic Slavic scholarship. The works of later structural scholars such as Eleazar Meletinsky $(1974,1976)$ were also being employed to some degree by a new generation of Celtic Slavic scholars. Toporov (1988) contributed to the Yartseva volume on Celtic scholarship in the Soviet Union and V. V. Ivanov (1964) wrote an important article on the origin of the name Cú Chulainn in which he demonstrated that the name is related to the IE myth of the victory of the hero over the monster with three heads, referring to such figures as Lugaid Mac Trí Con and to legends of dogheads, Conchenn, and to the Gaulish names, Cuno-pennus, Cuno-barrus, Cuno-vali. Both the battle with the three-headed monster and the transformation of the man into a werewolf have analogues in the Germanic and Slavic epic traditions, which had been previously discussed by Zhirmunsky. ${ }^{27}$

Present-day senior Russian Celtic scholars who have availed considerably from the insights of the various scholars and schools of learning previously mentioned are Alexander Falileyev, Tatyana

\footnotetext{
${ }^{27}$ On the question of Celtic canids, see further, K. McCone (1986, 1987), J. Carey (2002), and Phillip Andrew Bernhardt-House (2006). V. V. Ivanov also contributed to Celtic scholarship in various other studies, see, for example, Ivanov (1978).
} 
Mikhailova, Sergey V. Shkunayev and Nadezhda S. Shirokova. I have already had occasion to mention Dr Falileyev a number of times in the present contribution and his work is also discussed by Professor Tristram in her contribution to this volume. As to Professor Mikhailova, she has published approximately two hundred works of scholarship, quite a remarkable achievement at this stage of her career. She has perhaps not yet received the attention she deserves from scholars in the West, partly because her books have only recently been published and partly also because of the problems of reading works in the original Russian. She and Falileyev are closely connected with the recent renaissance of Celtic scholarship in Russia, particularly, as far as Mikhailova is concerned, in Moscow State University and the Academy of Sciences where she works. Both scholars are indefatigable workers, who not only lecture and publish prodigiously, but also organise conferences, function as editors and translators, and travel to conferences on Celtic matters on a regular basis.

Amongst Mikhailova's many publications are three monographs, one on 'Suibne Geilt', Irlandskoye predaniye o Suibne Bezumnom, ili vzglyad iz XII veka v VII (Buile Shuibne - Looking Back from the Twelfth Century to the Seventh = Mikhailova 1999); another on the allied subject of the concept and nature of 'geilt', Suibne-Gel't: zver' ili demon, bezumets ili izgoj (Geilt - Beast or Demon, Madman or Outlaw = Mikhailova 2001); and a third on the image of women in medieval Irish culture, Khozyajka sud'by: obraz zhenschiny v traditsionnoj irlandskoj kul 'ture (Harbinger of Death, Shaper of Destiny: the Image of a Woman in Irish Traditional Culture $=$ Mikhailova 2004a). She has also co-edited and contributed to Predstavleniya o smerti i lokalizatsiya Inogo Mira u drevnikh kel tov $i$ germantsev (Ideas of Death and the Location of the Otherworld in Early Celtic and Germanic Traditions = Mikhailova, Kalygin \& Toporova 2002 $)^{28}$ and the recently published Mifologema zhenschiny sud'by $u$ drevnikh kel'tov $i$ germantsev (The Mythologeme of the Woman and Fate among the Ancient Celts and Germans = Mikhailova 2005).

We may take her work on Buile Suibne (hereinafter $B S$ ) as an example of her contribution and of the manner in which she incorporates insights and methodologies gained from the Russian tradition of literary and philological scholarship. It is divided into chapters on Text and Genre, The

\footnotetext{
${ }^{28}$ See review by Fomin 2004.
} 
Historical Background, and King and Saint. Having discussed matters such as recensions and dating, she imposes a structural analysis on the material, identifying a system of dichotomies (male/female, sacred/profane, powerful/powerless, active/passive, etc.) in which the characteristics of protagonists are defined by the structure of the text and are independent of the characters themselves. She concludes that $B S$ is not a saga with the traditional system of characters typical of the epic tradition, but rather has to do with hagiography and the magical fairy tale. The historical background leads to an acceptance of Lotman's view that "history is the outcome of literacy" (Mikhailova 1999: 105). In the final section she deals, among other things, with the pragmatics of the curse of the saint and the poet, and the extraordinary efficacy of the name as a source of power and welfare in ancient societies, its introduction into the text in the context of the curse making it appear to be a ritual, an active original live spell.

Professor Mikhailova has also played a central role in ensuring that Early Irish texts are translated into Russian. She translated Celtic Heritage by the Rees Brothers (Mikhailova 1999a) and collaborated with S. V. Shkunayev in the production of the 1985 work Táin Bó Cúailnge (Pokhischeniye byka iz Kual'nge), which consists of a translation by Shkunayev of the Táin with translations of the remscéla by Mikhailova (Shkunayev \& Mikhailova 1985). Her recent publication of Sagi ob uladakh (Tales of the Ulstermen), to which Drs. N. Nikolayeva (O'Shea) and N. Chekhonadskaya also contributed (with some translations taken from Smirnov (1929) and Shkunayev (Shkunayev \& Mikhailova 1985) also), constitutes a major step forward in that it provides translations of 34 Medieval Irish texts, together with Introduction and Notes on the texts (Mikhailova 2004).

\section{Studies on Celtic and Irish History by Russian scholars}

S. V. Shkunayev and N. S. Shirokova also deserve our attention for having recently played an important role in Celtic Studies in Russia. As I have said, some of Shkunayev's translations are contained in Sagi ob uladakh, as is his article on 'Táin Bó Cúailnge and the legends about the Irish heroes' ('Pokhischeniye byka iz Kual'nge i predaniya ob irlandskikh geroyakh', repr. from Shkunayev \& Mikhailova 1985: 382-444). 
Shkunayev studied Ancient History at the University of Moscow between 1967 and 1972. He continued his studies at the Institute for General History of the Academy of Sciences of the Soviet Union; he is now a Leading Research Fellow at its successor Institute in the Russian Federation. In a number of papers (Shkunayev 1985, 1989, 1990, 1994, 1995) he has demonstrated a close interest in the interplay between the oral and the written word, between innovation and tradition in early Ireland and follows in the Lotman tradition of viewing writing as being one of the forms of collective memory, seeing, on the one hand, past texts as being remodelled to suit the present, with many variants and multiforms coming into being. Simultaneously, he points to the fixed traditional view of the world which tries to maintain order by constantly reproducing texts using symbolic signs such as natural phenomena as mnemonic devices. ${ }^{29}$ Shkunayev outlines how memory is sacred, and, how in written literature, texts relating to specific localities are heavily laden with oracles, prophecies and predictions.

Not only did Shkunayev initiate the translation of the Irish epic Táin Bó Cúailnge into Russian (see Shkunayev \& Mikhailova 1985), but he also translated numerous sagas for Predaniya i mify srednevekovoj Irlandii (Legends and Myths of Medieval Ireland = Shkunayev 1991). He furnished the collection with the Foreword, Commentary and Notes, and provided a further article on the Irish genealogical tradition.

N. S. Shirokova, born in 1938 , has made a significant contribution to our knowledge of the druids and of Celtic culture in the early period (Shirokova 1984, 1989, 2000). She graduated from Leningrad State University in 1963 in the History of Early Greece and Rome, took up a Research Fellowship at the State Hermitage between 1963 and 1972, and entered the Postgraduate Faculty of Leningrad State University in 1969. She took her $\mathrm{PhD}$ equivalent in 1975 with a thesis on 'Sotsial'naya $\mathrm{i}$ politicheskaya organizatsiya i ideologiya druidov' ('The Social and Political Organisation and Ideology of the Druids'), followed in 1991 by her Habilitation on 'Drevniye kel'ty na rubezhe staroj i novoj ery' ('Early Celts on the Threshold of the Old and New Era'). She was appointed in 1993 to a Professorship in the Department of Early Greece and Rome, and

\footnotetext{
${ }^{29}$ Lotman has written persuasively about this matter (Lotman 1990: 221-230).
} 
published Kul'tura kel'tov $i$ nordicheskaya traditsiya antichnosti (The Culture of the Celts and the Nordic Tradition of Antiquity) in 2000.

As regards the development of Modern Irish courses in Russia, the impact of Gary Bannister on the study of Modern Irish in Moscow should not go unnoticed. He taught at Moscow State University between 1977 and 1984 and exercised an important influence on scholars such as Tatyana Mikhailova and others. The support of the Irish Government in the establishment of the Irish Cultural Centre in the Philological Faculty of the University in 2001, which was officially opened by the Irish Ambassador, James Sharkey, was also indicative of the rising demand for, and interest in, Irish language and culture in the Russian capital.

I have not dealt directly in this paper with the contribution of Russian and Slavic scholarship to the Modern Celtic languages; nor has the influence of Russian literature on Irish and the other Celtic literatures been considered. Fortunately, the present volume contains papers by linguistic scholars working on various grammatical aspects of the Celtic and Slavic languages, and Dr Frank Sewell's contribution on the influence of Russian literature on Irish and Anglo-Irish literature fills in a number of gaps on literary matters.

\section{Conclusion: The Future of Russian Celtic Studies}

Celtic Studies is in a healthy state in Russia at present and Russian Celtic scholars have developed scholarly and cultural links and exchanges with many Celtic Studies Departments both in the Celtic countries and elsewhere throughout the world. The enthusiasm and great ability of the younger generation of Russian Celticists augurs well for the future development and success of the discipline. We may mention in conclusion, therefore, the younger scholars who are with us here today: Dr. Natalia O'Shea (Nikolayeva), presently based at Trinity College, Dublin, as a post-doctoral fellow of the Irish Research Council for the Humanities and Social Sciences, specialising in Indo-European and Early Irish linguistics (Nikolayeva 2001, 2001a (cf. 2002), 2003, 2004; Nikolayeva \& Mikhailova 2003); Dr Maxim Fomin, Secretary of the Societas and of the present Colloquium, Research Fellow at the Research Institute for Irish and Celtic Studies at the University of Ulster, Coleraine, specialising in Early Irish and Indic Studies (Fomin 1999, 2002, 2004a); Dr Grigory Bondarenko, 
Senior Research Fellow at the Institute of World History, Russian Academy of Sciences, and now Research Associate at the University of Ulster, Coleraine, specialising in Early Irish language and mythology (Bondarenko 2003); Dr Anna Muradova, Research Fellow of the Institute of Linguistics, specialising in Breton Studies (Muradova 2002, 2003), Dr Nina Chekhonadskaya, Lecturer at the Department of Ancient Languages, Historical Faculty, Moscow State University, specialising in the history of Celtic religion and Early Irish (Chekhonadskaya 2005; Mikhailova \& Chekonadskaya 2005); and Dr Elena Parina, Research Fellow of the Institute of Linguistics, Russian Academy of Sciences, specialising in Welsh linguistics (Parina 2003).

Professor Schmidt, Colleagues, it has not been possible to do justice to my subject in the short time available in the present talk but I hope that it has succeeded in throwing some light on the history, scope and achievement of Celtic scholarship in Russia and the former USSR. I thank you for your attention.

University of Ulster,

Coleraine 


\section{BIBLIOGRAPHY}

Bernardt-House, P. A., 2006, Canids in Celtic Cultures: From Celtiberia to Cú Chulainn to the Kennels of Camelot, unpublished Ph.D. thesis, University College Cork, 2006.

Bernstein, S. B., 1961, The Comparative Grammar of Slavonic Languages: a Sketch (= Ocherk sravnitelnoj grammatiki slavyanskikh yazykov) Moscow.

Beševliev, V., 1967, 'Keltische Ortsnamen in den Kastellverzeichnissen bei Prokopi', in: Actes du Premier Congrés international des etudes balcanique et sudest européenes. VI. Linguistique. Sofia, 415-423.

Best, R.I., 1942 (repr. 1969), Bibliography of Irish Philology and Manuscript Literature. Publications 1913-1941, Dublin: D.I.A.S.

Blažek, V., 1995, 'The Contribution of Václav Machek for Indo-European Etymology’, in: Slavia, 63, 499-501.

Blažek, V., 1999, 'The Tocharian and Celtic "span"', in: Tocharian and Indo-European Studies, 8, 85-86.

Blažek, V., 2001, 'Celtic-Anatolian Isoglosses', in: ZCP, 52, 125-128.

Blažek, V., 2001a, 'Balor - "the blind-eyed”?', in: ZCP, 52, 129-133.

Blažek, V., 2001b, Nominale Wortbildungdes älteren Irischen. Stammbildung und Derivation, by Patrizia De Bernardo Stempel, (Buchreihe der Zeitschrift für celtische Philologie, Bd. 15) Tübingen: Max Niemeyer Verlag, 1999) (review article), in: Word, 54, 3 (December), 413415.

Bondarenko, G., 2003, Mythology of Space in Early Irish Literature (= Mifologiya prostranstva drevnej Irlandii. In Russian: Мифология пространства древней Ирландии), Yazyk, Semiotika, Kul'tura: Series Minor. Moscow: Yazyki Slavyanskoj Kul'tury.

Buga, K., 1913, 'Kann man Keltenspuren auf baltischem Gebiet nachweisen? Aus Anlaß der Arbeiten Schachmatovs über keltischslavische und finnisch-keltische Beziehungen', in: Rocznik Slawistyczny, 6, 1-38. 
Buga, K., 1924, 'Die Vorgeschichte der aistischen (baltischen) Stämme im Lichte der Ortsnamenforschung', in: Streitberg Festgabe, Leipzig, 2235.

Čapková, V., 1987, 'The Freising Monuments', in: Ní Chatháin, P., \& Richter, M., eds., Irland und die Christenheit. Bibelstudien und Mission - Ireland and Christendom. The Bible and the Missions, Stuttgart, 461470.

Čapková, V., \& Ahlqvist, Anders, eds., 1997, Dán do Oide: Essays in Memory of Conn R. Ó Cléirigh (1927-1995), Dublin: The Linguistics Institute of Ireland.

Chekhonadskaya, N., 2005, 'The Gaulish Prophetesses: Life, Death and Healing in the Hands of the Gaulish Women', in: Mikhailova, T.A., ed., Harbinger of Death, Shaper of Destiny (= 'Gal'skiye prorochitsy'. In Russian: 'Галльские пророчицы: жизнь, смерть и исцеление в руках галльских женщин', Мифологема женщины-судьбы удревних кельтов и германцев. Под ред. Михайловой Т.А.), Moscow, 282-320.

Dashkevich, N. P., 1886, 'The Early Celtic Epic and the Bylina Songs of Kiev Rus', (= 'Drevne-kel'tskij narodnyj epos o korolye Arturye i vityazyakh Kruglogo Stola i byleviye pesni Kiyevo-Galitskoj Rusi’. In Russian: 'Древне-кельтский народный эпос о короле Артуре и витязях Круглого Стола и былевые песни Киево-Галицкой Руси'), in: Izvestiya Kievskogo Universiteta, 9, 10, 12.

Duridanov, I., 1997, 'Keltische Sprachspiren in Thrakien und Mösien', in: ZCP, 49-50, 130-42.

Dybo, V. A., 1961, 'Shortening of Lengths in Celto-Italic Languages and its Significance for Balto-Slavic and IE Accentology' (= 'Sokrascheniye dolgot $\mathrm{v}$ kel'to-italijskikh yazykakh i ego znacheniye dlya baltoslavyanskoj i indoevropejskoj aktsentologii'. In Russian: 'Сокращение долгот в кельто-италийских языках и его значение для балтославянской и индо-европейской акцентологии'), in: Voprosy slavyanskogo yazykoznaniya, 5 .

Falileyev, A., \& Isaac, G., 1998, 'Welsh cabl "calumny, blame, blasphemy", in: $I F, 103,202-206$. 
Falileyev, A., \& Isaac, G., 2003, 'Leeks and Garlic: The Germanic Ethnonym Cannenefates, Celtic *kasn- and Slavic *kesn-', in: NOWELE, 42, March, 3-12.

Falileyev, A., 1990-91, 'The Present State of Celtic Studies in the USSR', in: Australian Celtic Journal, 3, 56-60.

Falileyev, A., 1997-98, 'Cambro-Slavica', in: ZCP, 49-50, 198-203.

Falileyev, A., 1999, 'Celto-Slavica', in: ZCP, 51, 1-3.

Falileyev, A., 2000, Etymological Glossary of Old Welsh, Tübingen.

Falileyev, A., 2001, 'Celto-Slavica II', in: ZCP, 52, 121-124.

Falileyev, A., 2002, The Old Welsh (= Drevnevalijskij yazyk. In Russian: Древневаллийский язык), St. Petersburg: Nauka.

Falileyev, A., 2002a, 'Ptolemy, Revisited, Again', in: CMCS, 43, Summer, 77-91.

Falileyev, A., 2003, The Old Welsh Language in the Synchrony and the Diachrony (= Drevnevalijskij yazyk v sinchronii i diachronii. In Russian: Древневаллийский язык в синхронии и диахронии), Moscow: RAN, Institut yazykoznaniya.

Falileyev, A., 2003-2004, 'Ein neues Projekt über ein Computer-Korpus der thrakischen Sprache', in: Orpheus 13-14. Memorial Volume to Georgi Rikov, 99-102.

Falileyev, A., 2004, 'Place-names and Ethnic Groups in North-Western Dacia: a Case for Celtic', in: Thracians and Circumpontic World. Proceedings of the Ninth International Congress of Thracology. 6-11 September 2004. Chişinău, 34-38.

Falileyev, A., 2005, 'In Search of Celtic Tylis: Onomastic Evidence', in: de Hoz, J., Luján, E.R., \& Sims-Williams, P., eds., New Approaches to Celtic Place-Names in Ptolemy's Geography, Madrid: Ediciones Clásicas, 107-133.

Falileyev, A., 2005a, 'Paleobalkan Studies: Aspects of Segmentation of Non-indigenous Data', in: Sawicka, I., ed., Studia Albanica II. In memoriam Wactaw Cimochowski, Toruń, 55-64.

Falileyev, A., 2005b, 'Celts in Roman Dacia: Galatian Factor' ('Kel'ty v rimskoj Dakii'. In Russian: 'Кельты в римской Дакии: галатский 
THE HISTORY OF CELTIC SCHOLARSHIP IN RUSSIA AND THE SOVIET UNION

фактор'. Балканские чтения 8. В поисках “западного” на Балканах. Предварительные материалы) Moscow, 40-44.

Falileyev, A., 2005c, 'ГА АATIKA', in: Kazanskij, N. N., ed., Hrdă mánasā (Сборник статей к 70-летию со дня рождения профессора Л.Г. Гериенберга), St. Petersburg: Nauka, 301-307.

Falileyev, A., 2005d, 'Celtic Presence in Dobrudja: Onomastic Evidence', in Cojocaru, V., ed., Ethnic Contacts and Cultural Exchanges North and West of the Black Sea from the Greek Colonisation to the Ottoman Conquest, Iaşi, 291-303.

Falileyev, A., 2006, 'Gaulish $s$, IE * $p$ and some Aspects of Interpretation of the Continental Celtic Data' ('Gal'sk. $s$, i.-e. *p i nekotoriye aspekty interpretatsii kontinental'nykh kel'tskikh dannykh'. In Russian: 'Галльск. $s$, и.-е. * $p$ и некоторые аспекты интерпретации континентальных кельтских данных (Памяти В.П. Калыгина)'. Индоевропейское языкознание и классическая филология Х. Материаль чтений. посвященных памяти профессора И.М. Тронского), St. Petersburg: Nauka, 306-313.

Falileyev, A., fc., Walter of Henley. Anglo-Norman Texts and Welsh Translations, Dublin: Dublin Institute for Advanced Studies.

Filip, J., 1956, Die Kelten in Mitteleuropa, Prague.

Filip, J., 1961, Die keltische Zivilisation und ihr Erbe, Prague.

Fomin, M., 1999 (2003), 'The Early Medieval Irish and Indic Polities and the Concept of Righteous Ruler', in: Cosmos, 15, 1 \& 2, 167-201.

Fomin, M., 2002, The Notion of Righteous Ruler in Early Irish and Early Indian Sources (Kontseptsiya pravyednogo pravleniya. In Russian: Конщепџия праведного правления на материале источников раннесредневековой Ирландии и древней Индии. Дисс. канд. филос. н. Москва, МГУ), unpublished $\mathrm{PhD}$ dissertation, Moscow State University.

Fomin, M., 2004, 'On the Notions of Death, Navigation and Otherworld', in: $C M C S, 47$, Summer, 73-79.

Fomin, M., 2004a, 'Exploring Connections between Celtic and Indian Studies: Pitfalls and Fascinations of Comparative Approach', in: International Congress of Asian and North African Studies. Abstracts, Moscow, 227. 
Frey, O. H., \& Szabó, M., 1991, 'The Celts in the Balkan Area', in: Moscati, S., Frey, O. H., Venceslas, K., Raftery, B., \& Szabó, M., eds., The Celts, Milano: Bompiani, 378-84.

Gołąb, Z., 1972, “'Kentum” Elements in Slavic', in: Lingua Posnaniensis, $16,53-82$.

Goląb, Z., 1975, 'Veneti/Venedi - The Oldest Name of the Slavs', in: Journal of Indo-European Studies, 3, 4, 321-336.

Goląb, Z., 1992, The Origins of the Slavs: A Linguist's View. Columbus: Slavica Publishers.

Gurevich, A. J., 1972, Kategorii srednevekovoj kul'tury, Moscow (= Categories of Medieval Culture (English transl. by Campbell, G. L.), London - Boston: Routledge \& Kegan Paul, 1985).

Ivanov, V. V., 1958, 'Problem of the centum and satem Languages' (= 'Problema jazykov centum i satem'. Published in Russian: 'Проблема языков centum и satem'), Voprosy Jazykoznanija, 4, 12-23.

Ivanov, V. V., 1964, 'The Origin of the Name Cú Chulainn' (= 'Proiskhozhdeniye imeni Kukhulina'. In Russian: 'Происхождение имени Кухулина'), in: Alekseyev, M. P., \& Meletinsky, E.M., eds., Problemy sravnitelnoj filologii. Sbornik statej $k$ 70-letiyu $V . \quad M$. Zhirmunskogo, Moscow - Leningrad: Nauka, 451-61.

Ivanov, V. V., 1978, 'Some Aspects of Interpretation of the Ritual and Mythological Terms, derived from aśva, 'horse', (Horse-sacrifice and aśvattha Tree in Early India)' (= 'Opyt istolkovaniya ritual'nykh i mifologicheskikh terminov, obrazovannykh ot aśva "kon' "'. In Russian: Вяс. Вс. Иванов, 'Опыт истолкования ритуальных и мифологических терминов, образованных от aśva, 'конь' (жертвоприношение коня и дерево aśvattha в древней Индии)'. Проблемы истории языков и культуры народов Индии: сборник статей памяти В.С. ВоробьеваДесятовского), Moscow, 75-138.

Jovanović, B., 1984, 'Les sépultures de la nécropole celtique de Pécine près de Kostolac', in: Études Celtiques, 21, 63-93.

Jovanović, B., \& Jovanović, M., 1988, Gomolava - Late La Tène Settlement (= Gomolava - naselje mlađeg gvozdenog đoba). Novi Sad Beograd. 
Jovanović, B., 1992, 'Celtic Settlements in the Balkans', in: Tasić, N., ed., Scordisci and the Native Population in the Middle Danube Region, Belgrade, 19-32.

Kalygin, V. P., \& Korolyov, A. A., 1989, Introduction to Celtic Philology (=Vvedeniye v kel'tskuyu filologiyu. Published in Russian: Введение в кельтскую филологию), Moscow: Nauka. $2^{\text {nd }}$ ed. (2006; with appendices) Moscow: Editorial URSS.

Kalygin, V. P., 1986, The Language of the Earliest Irish Poetry (= Yazyk drevnejshej irlandskoj poezii. Published in Russian: Язык древнейтей ирландской поэзии), Moscow: Nauka; $2^{\text {nd }}$ ed. (2003) Moscow: Editorial URSS (= La langue de la poésie irlandaise archä̈que (French translation by Le Berre, Y. (Brest); edited by Tristram, H. L. C. (Freiburg i. Brsg.), Hamburg: Helmut Buske Verlag, 1993 (review Corthals, J., 1994, CMCS, 27, 93)).

Kalygin, V. P., 1991, 'Principes de l'organisation phonique du texte dans la poésie irlandaise archaique', in: Tristram, H. L. C., ed., Metrik und Medienwechsel, Tübingen, 189-195.

Kalygin, V. P., 1992, 'Quelques aspects mythologiques de la tradition grammaticale vieil-irlandaise’, in: Études Celtiques, 29, 241-248.

Kalygin, V. P., 1994, 'Indogermanische Dichtersprache und altirische mythopoetische Tradition', in: Vortrag in memoriam R. Thurneysen, ZCP, 46, 1-10.

Kalygin (= Kalyguine), V. P., 1997, 'Deux correspondences de vocabulaire mythologique entre les langues celtiques et balto-slaves', in: ZCP, 49-50, 367-72.

Kalygin, V. P., 2003, 'The Celts and the Slavs' (= 'Kel'ty i slavyane'. In Russian: 'Кельты и славяне'), in: Sravnitelno-istoricheskoyeissledovaniye yazykov: sovremennoye sostoyaniye i perspektivy, Moscow, 86-89.

Ködderitzsch, R., 1993, 'Keltisch und Thrakisch', in: Akten des ersten Symposiums deutschsprachiger Keltologen, Tübingen, 139-57.

Korolyov, A. A., 1971, 'On the Noun Plural Formations in the Modern Dialects of the Scottish Gaelic' (= 'Sposoby obrazovanija form mnozhestvennogo chisla imen suschestvitel'nykh v sovremennykh dialektakh shotlandskogo yazyka'. In Russian: 'Способы образования 
форм множественного числа имен существительных в современных диалектах шотландского (гэльского) языка'. Синхронносопоставительный анализ языков разных систем), Moscow, 122141.

Korolyov, A. A., 1972, 'On Certain Innovations in the System of the Plural in the Early Irish Language' (= 'O nekotorykh innovatsiyakh v sisteme mnozhestvennogo chisla drevneirlandskogo yazyka'. In Russian: 'O некоторых инновациях в системе множественного числа древнеирландского языка'. Историко-типологические и синхроннотипологические исследования), Moscow, 28-37.

Korolyov, A., 1974, 'Some Remarks relating to the History of the Irish Noun Conjugation' (= 'Nekotoriye voprosy istorii irlandskogo imennogo skloneniya'. In Russian: 'Некоторые вопросы истории ирландского именного склонения'), in: Yartseva, V. N, ed., Kel'ty i kel'tskiye yazyki, Moscow: Nauka, 84-94.

Korolyov, A. A., 1984, The Oldest Monuments of the Irish language (= Drevnejshiye pamyatniki irlandskogo yazyka. Published in Russian: Древнейшие памятники ирландского языка), Moscow: Nauka.

Korolyov, A. A., 1988, 'Philological Methods in the Study of History of the Celtic Languages' (= 'Filologicheskiye metody v issledovanii istorii kel'tskikh yazykov'. In Russian: ‘Филологические методы в исследовании истории кельтских языков'. Сравнительноисторическое изучение языков разных семей), Moscow, 119-138.

Korolyov, A. A., 1990, 'The Welsh Language' (= 'Valijskij yazyk'. In Russian: 'Валлийский язык'. Лингвистический энциклопедический словарь), in: Linguistic Encyclopaedic Dictionary, Moscow, 80.

Korolyov, A. A., 1990a, 'The (Scottish) Gaelic Language' (= 'Gel'skij yazyk'. In Russian: 'Гэльский язык'. ЛЭС), in: Linguistic Encyclopaedic Dictionary, Moscow, 126.

Korolyov, A. A., 1990b, 'The Irish Language' (= 'Irlandskij yazyk'. In Russian: 'Ирландский язык'. ЛЭС), in: Linguistic Encyclopaedic Dictionary, Moscow, 200-201.

Korolyov (= Korolev), A. A., 1994, 'The co-cloth Formula and its Possible Cultural Implications', in: J. P. Mallory and G. Stockman, eds., Ulidia: 
THE HISTORY OF CELTIC SCHOLARSHIP IN RUSSIA AND THE SOVIET UNION

Proceedings of the First International Conference on the Ulster Cycle of Tales, Belfast, Emain Macha, 251-3.

Korolyov, A.A., 1995, 'Early Irish fo•naisc, fonaidm, 'binds, imposes', and Vedic Sóma úpanaddhạ, 'Bound Soma': Common Indo-European Heritage?', in: Language and Culture of the Celts. Proceedings of the Fourth Colloquium. St. Petersburg ('Drevneirlandskoye fo naisc, fonaidm "svyazyvat', podvyazyvat"” i vedicheskoye Sóma úpanaddhah “podvyazannyj Soma”: obscheindoevropejskoye naslediye?'. In Russian: А.А. Королев, 'Древнеирландское fo-naisc, fonaidm "связывать, подвязывать" и ведическое Sóma úpanaddha "подвязанный Сома": общеиндоевропейское наследие?', Язык и культура кельтов. Mатериальь IV коллоквиума, Санкт-Петербург) 12-13.

Kryukova, I. V., 1974, 'The verbs beirim and bheirim in the Modern Irish' (= 'Glagoly beirim i bheirim v sovremennom irlandskom yazyke'. In Russian: 'Глаголы beirim и bheirim в современном ирландском языке'), in: Yartseva, V. N, ed., Kel'ty i kel'tskiye yazyki, Moscow: Nauka, 105-111.

Kryukova, I. V., 1987, Verbal Change in the Irish Language (= Glagol'noye slovo-izmeneniye v irlandskom yazyke. Published in Russian: Глагольное словоизменение в ирландском языке). Leningrad: Nauka, Akademiya Nauk SSSR.

Kryukova, I. V., 1995, 'Irish-English Language Contact and Interference' (= 'Yavleniye grammaticheskoj interferentsii $\mathrm{v}$ usloviyakh irlandskoanglijskogo kontaktirovaniya'. Published in Russian: 'Явление грамматической интерференции в условиях ирландско-английского контактирования'), in: Borodina, М. А., Kuzmenko, Yu. K., eds., Etnicheskiye kontakty $i$ yazykoviye izmeneniya, (Ethnic Contact and Language Change), St. Petersburg: Nauka, 165-183.

Kuryłowicz, J., 1961a, 'Celtic-Slavonic Language Contacts' (= 'Celtyckosłowiańskie stosunki językowe’), in: Kowalenko, W., Labuda, G., \& LehrSpławiński, T., eds., Stownik Starożytności Stowiańskich. Encyklopedyczny zarys kultury Stowian od czasów najdawniejszych, 1, 2, 229-230.

Lehr-Splawiński, T., 1946, On the Origin and the Motherland of the Slavs (= O pochodzeniu i praojczyznie Slowian), Poznan. 
Lehr-Spławiński, T., 1956a, 'Some Remarks on Celtic-Proto-Slavonic Language Contacts' (= 'Kilka uwag o stosunkach językowych celtyckoprasłowiańskich'), in: Rocznik Slawistyczny, 18, 1-10.

Lehr-Splawiński, T., 1956b, 'On Celtic-Slavonic Language Contacts' (= 'Ze stosunków językowych celtycko-słowiańskich'), in: Zeszyty Naukowe Uniwersytetu Jagiellońskiego, Filologia 2: Prace Językoznawcze, Kraków: Wydawnictwo Uniwersytetu Jagiellońskiego, 256.

Lotman, Y. M., 1990, Universe of the Mind: A Semiotic Theory of Culture. Transl. by Ann Shukman. Introduction by Umberto Eco. London - New York: I.B. Tauris.

Machek, V., 1948, Josef Baudiš, Praha: Čes. Akademie.

Machek, V., 1963, 'Zur Frage der slawisch-keltischen sprachlichen Beziehungen', in: Studia linguistica in honorem Thaddei Lehr-Splawinski, Warszawa: Panstwowe Wydawnictwo Naukowe, 109-20.

Machinsky, A. D., 1974, 'Celts at the Lands to the East of the Carpathian Mountains' (= 'Kel'ty na zemlyakh k vostoku ot Karpat'. In Russian: 'Кельты на землях к востоку от Карпат'), in: Yartseva, V. N, ed., Kel'ty i kel 'skiye yazyki, Moscow: Nauka, 31-41.

Majnarić-Pandžić, N., 1970, The Celtic Laten Culture in Srijem, Slavonia (= Keltsko latenska kultura u Slavoniji i Srijemu), Vinkovci.

Martynov, V. V., 1983, Language in Space and Time (= Yazykv prostranstve i vremeni. In Russian: Язык в пространстве и времени) Moscow.

Matasović, R., 2003, Concise Grammar of Old Irish Language (= Kratka gramatika staroirskogo jezika s poredbenopovijesnim objašnjenjima), Zagreb.

Matasović, R., 2003a, 'Linguistic Traces of Celts in Illyricum' (= 'Jezični tragovi Kelta u Iliriku'), in: Latina et Graeca, 3, 5-23.

Matasović, R., 2004, Medieval Irish Sagas (= Kamen Kraljeva. Srednjovjekovne irske sage), Zagreb.

McCone, K., 1986, 'Werewolves, Cyclopes, Díberga, and Fíanna: Juvenile Delinquency in Early Ireland', CMCS, 12, 1-22.

McCone, K., 1987, 'Hund, Wolf und Krieger bei den Indogermanen', in: Meid, W., ed., Studien zum indogermanischen Wortschatz, (Innsbrucker Beiträge zur Sprachwissenschaft 52), Innsbruck, 101-150. 
THE HISTORY OF CELTIC SCHOLARSHIP IN RUSSIA AND THE SOVIET UNION

Meletinsky, E. M., 1974, 'Structural-Typological Study of Folktales', in: Sebeok, T.A., ed., Approaches to Semiotics, Mouton, 19-53. [Transl. from German, 'Zur strukturell-typologischen Erforschung des Volkmärchens', Deutsches Jahrbuch für Volkskunde, 15 (1969), 1-30].

Meletinsky, E. M., 1976, Poetics of Myth. (= Poetika myfa. Published in Russian: Поэтика мифа), Moscow: Nauka.

Mikhailova, T. A., 1999, Buile Suibne - Looking back from $12^{\text {th }}$ Century to the $7^{\text {th }}$. (= Irlandskoye predaniye o Suibne Bezumnom, ili vzglyad iz XII veka $v$ VII. Published in Russian: Ирландское предание о Суибне Безумном, или взгляд из XII века в VII), Moscow: MGU.

Mikhailova, T. A., 1999a, trans., Rees, A. \& B., Celtic Heritage. (In Russian: А. и Б. Рис, Наследие кельтов. Древняя традищия в Ирландии и Уэльсе. Серия “История духовной культуры”, пер. с англ.; статья “Наследие Рисов (вместо послесловия)" Михайловой Т. А.) Moscow: Enigma.

Mikhailova, T. A., 2001, Suibhne-Geilt-Beast or Demon, Madman or Outlaw. (= Suibne-Gel't: zver'ili demon, bezumets ili izgoj. Published in Russian: Суибне-Гельт: зверь или демон, безумеи или изгой), Moscow: Agraf.

Mikhailova, T. A., 2004, ed. and transl. (with Chekhonadskaya, N., and Nikolaeva, N.), Tales of the Ulstermen (= Sagi ob uladakh. Published in Russian: Саги об уладах), Moscow: Agraf.

Mikhailova, T. A., 2004a, Harbinger of Death, Shaper of Destiny: the Image of Women in Irish Culture. (= Khozyajka sud'by. Obraz zhenschiny $v$ traditsionnoj irlandskoj kul ture. Published in Russian: Хозяйка судьбы. Образ женщины в традищионной ирландской культуре). Moscow: Yazyki Slavyanskoj Kul’tury.

Mikhailova, T. A., ed., 2005, The Mythologeme of the Woman and Fate among the Ancient Celts and Germans (= Mifologema zhenshiny sud'by $u$ drevnikh keltov $i$ germantsev. Published in Russian: Мифологема женщины-судьбы у древних кельтов и германцев), Moscow: Indrik.

Mikhailova, T. A., \& Chekonadskaya, N., 2005, 'The Gaulish Tablet from Larzak: its Pragmatics and Genre' (= 'Gal'skaya "tablichka iz Larzaka”: pragmatika i zhanr'. In Russian: 'Галльская “табличка из 
Ларзака": прагматика и жанр'. Заговорный текст: генезис и структура), Moscow, 73-92.

Mikhailova, T. A., Kalygin, V. P., \& Toporova, T. V., 2002, eds., Ideas of Death and Location of the Otherworld in Early Celtic and Germanic Traditions. (= Predstavleniya o Smerti i Lokalizatsiya Inogo Mira u Drevnikh Kel'tov $i$ Germantsev. Published in Russian: Представления о смерти и локализация Иного мира у древних кельтов и германцев). Yazyk, Semiotika, Kul'tura: Series Minor. Moscow: Yazyki Slavyanskoj Kul'tury.

Milewski, T., 1961, 'Die stolzen Namen der Kelten', in: Bibliotheca Classica Orientalis, 6, 114-115.

Muradova, A., 2002, 'Ankou, Personification of Death: Death-Messenger or Weapon of Death' (= 'Anku: personifikatsiya smerti, vestnik smerti ili orudiye smerti’. In Russian: ‘Анку: персонификация смерти, вестник смерти или орудие смерти'. Представления о смерти и локализация Иного мира у кельтов и германщев, под ред. Т. А. Михайловой), Moscow, 315-339.

Muradova, A., 2003, 'Social-linguistic Situation in Armorica in the 1-6 centuries AD' (= 'Model' sociolingvisticheskoj situatsii v Armorike v 1-6 vv.'. In Russian: 'Модель социолингвистической ситуации в Арморике в 1-6 вв. (взаимодействие галльского, бриттского и латинского языков). Теория, история, типология языков. Материаль чтений памяти В. Н. Яризевой. Выпуск 1), Moscow, 241-248.

Nikolayeva, N., \& Mikhailova, T. A., 2003, 'The Denotations of Death in Goidelic: to the Question of Celtic Eschatological Conceptions', in: ZCP, $53,93-115$.

Nikolayeva, N., 2001, 'On the Phonology of the OIr. Names Amlaíb, Ímar, Tomrair', in: Kirk, J. M., \& Ó Baoill, D. P., eds., Language Links: the Languages of Scotland and Ireland, Belfast, 116-118.

Nikolaeva, N., 2001a, 'The Drink of Death', in: Studia Celtica, 35, 299306.

Nikolayeva, N., 2002, 'The Drink of Death' (= 'Pit'jo smerti'. In Russian: 'Питье смерти'. Представления о смерти и локализация Иного мира у кельтов и германцеев, под ред. Т. А. Михайловой) Moscow, 48-60. 
Nikolayeva, N., 2003, 'Abnomal Forms of OIr. Suffixless Preterite: OIr. fiu and Others' (= 'Anomal'niye formy dr.-irl. bessufiksal'nogo preterita'. In Russian: Аномальные формы др.-ирл. бессуфиксального претерита: др.-ирл. fü и другие'. Язык и культура кельтов. Материаль 9 коллоквиума), St. Petersburg, 84-95.

Nikolayeva, N., 2004, 'Regarding the IE Nasal Presence in Germanic Languages (with a Special Reference to Gothic)' (= 'O sud'be indoevropejskogo nazal'nogo prezensa'. In Russian: 'О судьбе индоевропейского назального презенса в германских языках (на материале готского языка)', Сравнительно-историческое исследование языков: современное состояние и перспективы (сборник статей по материалам конференции)), Moscow, 280-290.

Pallas, Peter Simon, 1787-89, Linguarum totius orbis vocabularia comparativa ( $2^{\text {nd }}$ edition, 1790-91), St. Petersburg.

Parina, E., 2003, 'Comparative Analysis of Translations of the Four Branches of the Mabinogion' (= 'Sravnitel'nyj analiz perevodov “chetyryokh vetvej Mabinogi”'. In Russian: 'Сравнительный анализ переводов “четырех ветвей Мабиноги" (на примере одного энглина из Math uab Mathonwy)'. Язык и культура кельтов. Материаль 9 коллоквиума), St. Petersburg, 96-104.

Pokorny, J., 1936, 'Illyrisch, Baltisch und Keltisch', in: ZCP, 20, 511519.

Popović, P., 1977, Le Monnayage des Scordisques. Les monnaies et la circulation monétaire dans le centre de Balkans $I V^{e}-I^{e r}$ av. n. è., Beograd - Novi Sad.

Popović, P., 1991, 'Late Iron Age of the Iron Gate Region' (= 'Mlađe gvozdeno doba Đerdapa'), in: Starinar, 40-41, 165-176.

Popović, P., \& Vukmanović, M., 1998, Vajuga-Pesak. Early Iron Age Cemetery, Cahiers des Portes de Fer (Monographies 3), Belgrade.

Propp, V. J., 1928, Morphology of the Folktale (= Morfologiya volshebnoj skazki. Published in Russian: Морфология “волшебной” сказки), Leningrad. English trans. Scott, L., 1958, Bloomington, Ind: Research Center, Indiana University. 
Propp, V. J., 1958, Russian Heroic Epic (= Russkij geroicheskij epos), Moscow.

Rozwadowski, J. M., 1897, 'Grammatical and etymological investigations' (= ' $\mathrm{Z}$ zagadnień gramatycznych i etymologicznych'), in: Rozprawy Wydziału Filologicznego Akademii Umiejętności, 25, Kraków, 389-427.

Rudnicki, M., 1936, 'Die Slaven, Kelten und Germanen in Bassin des Baltischen Meeres zu Beginn der indoeuropäischen Ära', in: Slavia Occidentalis, 15, 131-141.

Schmid, W. P., 1976, 'Baltische Sprachen und Völker', in: von Hoops, J., ed., Reallexikon der Germanischen Altertumskunde, $2^{\text {nd }}$ ed., 2, Berlin, New York, 14-20.

Schmidt, K. H., 1985, 'Keltisch, Baltisch und Slavisch', in: Melena, J. L., ed., Symbolae Lvdovico Mitxelena Septuagenario oblatae, 1, VitoriaGasteiz: Instituto de Ciencias de la Antigüedad, Universidad del Pais Vasco, 23-29.

Schmidt, K. H., 1992, 'The Celtic Problem. Ethnogenesis (Location, Date?)', in: ZCP, 45, 38-65.

Schmidt, K. H., 1996, Celtic: A Western Indo-European Language? IBS Vortrage und Kleinere Schriften, 66, Innsbruck.

Schukin, M. V., 1974, 'Celtic-Dakian Monuments on the Threshold of Our Era and the Lipetsk Culture' (= 'Kel'to-dakijskiye pamyatniki rubezha ery i lipetskaya kul'tura'. In Russian: 'Кельто-дакийские памятники рубежа нашей эры и липетцкая культура'), in: Yartseva, V. N, ed., Kel 'ty i kel 'tskiye yazyki, Moscow: Nauka, 14-22.

Sedov, V. V., 1998, 'The Slavonic World before the Disintegration of the Linguistic Community' (= 'Slavyanskij mir nakanune raspada yazykovoj obschnosti'. In Russian: 'Славянский мир накануне распада языковой общности'), in: Slavyanskiye literatury. Kul'tura i fol'klor slavyanskikh narodov. 12-j mezhdunarodnyj s'ezd slavistov. Doklady rossijskoj delegatsii, Moscow.

Sedov, V. V., 2002, The Slavs (= Slavyane. Istoriko-arkheologicheskoye issledovaniye), Moscow.

Shakhmatov (= Schachmatow), A. A., 1911, 'Zu den ältesten slavischkeltischen Beziehungen', in: Archiv für Slavische Philologie, 33, 51-99. 
THE HISTORY OF CELTIC SCHOLARSHIP IN RUSSIA AND THE SOVIET UNION

Shirokova, N. S., 1984, Celtic Druids (= Kel'tskiye druidy. Published in Russian: Кельтские друиды), Moscow: Nauka.

Shirokova, N. S., 1989, Early Celts on the Threshold of the Old and the New Era (= Drevniye kel'ty na rubezhe staroj i novoj ery. Published in Russian: Древние кельты на рубеже старой и новой эры), Leningrad: Leningrad University Publishers.

Shirokova, N. S., 2000, The Culture of the Celts and the Nordic Tradition of Antiquity. (= Kul'tura kel'tov $i$ nordicheskaya traditsiya antichnosti. Published in Russian: Культура кельтов и нордическая традиция античности). St. Petersburg: Eurasia.

Shkunayev, S. V., 1985, 'Celtic Myth in the Saga about the King Conaire' (= 'Kel’tskij mif v sage o korolye Konajre'. In Russian: 'Кельтский миф в саге о короле Конайре'), VDI, 3.

Shkunayev, S. V., 1989, Community and Society of the Western Celts (= Obschina i obschestvo zapadnykh kel'tov. Published in Russian: Община и общество западных кельтов). Moscow: Nauka.

Shkunayev, S. V., 1990, 'Continuity of Tradition in Early Christian Ireland (= 'Preemstvennost' traditsii v rannekhristianskoj Irlandii'. Published in Russian: 'Преемственность традиции в раннехристианской Ирландии'), in: VDI, 4, 34-48.

Shkunayev, S. V., ed. and transl., 1991, The Lore and the Myths of Medieval Ireland (= Predaniya i mify srednevekovoj Irlandii. Published in Russian: Предания и мифы средневековой Ирландии. Сост., пер., вступит. ст., комм. и прил. "Несколько замечаний по поводу раннеирландской генеалогической традиции” Шкунаева, С. В.), Moscow: MGU.

Shkunayev (= Shkunaev), S. V., 1994, 'Variability of the Written Text: Aspects of Early Irish Literacy', in: Tristram, H. L. C., ed., Text und Zeittiefe (ScriptOralia, 58), Tübingen, 525-29.

Shkunayev, S. V., 1995, 'The Early Irish Tradition and its Pagan Past: the Problems and the Perspectives of its Study' (= 'Ranneirlandskaya traditsiya i yazycheskoye proshloye: problemy i perspektivy'. In Russian: 'Раннеирландская традиция и языческое прошлое: проблемы и перспективы изучения'), in: VDI, 3, 38-47. 
Shkunayev, S. V., \& Mikhailova, T. A., eds. and trans1., 1985, Cattle-raid of Cuailnge (= Pokhischeniye byka iz Kual'nge. In Russian: Похищение быка из Куальнге. Сер. “Литературные памятники”. Пер. и сост. Михайловой, Т.А., Шкунаева, С.В.; статья “«Похищение быка из Куальнге» и предания об ирландских героях" и прим. Шкунаева, С. B.), Moscow: Nauka.

Smirnov, A. A., 1912, R. Edens. Erec-Geraint (review article), in: Revue Celtique, 33, 1, 130-137.

Smirnov, A. A., 1913, 'A propos d'un prétendu témoignage sur les reunions des bardes en Bretagne au X-e siècle', in: Revue Celtique, 34, 3, 287-289.

Smirnov, A. A., 1913a, W. Foerster. Wilhelm von England (Guillaume d'Angleterre), ein Abenteuerroman von Kristian von Troyes (review article), in: Romania, 42, 166, 282-287.

Smirnov, A. A., 1914, J. Loth. Contributions à l'étude des romans de la Table Ronde (review article), in: Romania, 43, 169, 119-126.

Smirnov, A. A., 1915, 'Irish Saga Aided Muirchertach meic Erca' (= 'Irlandskaya saga o smerti korolya Muirkhertakha, syna Erk'. In Russian: 'Ирландская сага о смерти короля Муйрхертаха, сына Эрк'), in: Zapiski neofilologicheskogo obschestva, 8, Peterburg.

Smirnov, A. A., 1928, 'Contribution à l'étude de la vie provençale de Peire Vidal', in: Romania, 54, 214, 261-266.

Smirnov, A. A., ed. and trans1., 1929, Irish Sagas (= Irlandskiye Sagi. Published in Russian: Ирландские саги $),\left(1^{\text {st }}\right.$ ed. $1929,2^{\text {nd }}$ ed. $1933,3^{\text {rd }}$ ed. 1961), Moscow-Leningrad (review Vendryes, J., 1930, Revue Celtique, 47, 267-68).

Smirnov, A. A., Mokul'sky, S. S., Zhirmunsky, V. M., Alekseyev, M. P., eds., 1947, The History of Western European Literature. Early Medieval Ages and Renaissance (= Istoriya zapadnoevropejskoj literatury. Ranneye srednevekov'ye i Vozrozhdeniye. In Russian: Мокульский С. С., Жирмунский В. М., Смирнов А. А., Алексеев М. П. История западноевропейской литературы. Раннее средневековье и Возрождение), Leningrad, $2^{\text {nd }}$ ed. 1959, $3^{\text {rd }}$ ed. 1987 (Moscow: Vysshaya Shkola). 
THE HISTORY OF CELTIC SCHOLARSHIP IN RUSSIA AND THE SOVIET UNION

Smirnov, A. A., trans1., 1954, Lewis G. \& Pedersen H., Concise Grammar of Celtic Languages (= Льюис Г., Педерсен Х. Краткая сравнительная грамматика кельтских языков). Moscow.

Stalmaszczyk, P., \& Witczak, K. T., 1995, 'Celto-Slavic Language Connections: New Evidence for Celtic Lexical Influence upon ProtoSlavic', in: Kurytowicz Memorial Volume, 2 (Linguistica Baltica, 4), Cracow, 225-232.

Stalmaszczyk, P., \& Witczak, K. T., 2001, 'On Two Baltic-Celtic Terms for 'stallion", in: Marcinkiewicz, J., Ostrowski, N., eds., Poznanskie Studia Baltystyczne, 1 (Munera Linguistica et Philologica Michaeli Hasiuk Dedicata), Poznań: Katedra Skandynawistyki i Baltologi, 29-32.

Stalmaszczyk, P., \& Witczak, K. T., 2002, 'Etyma Celtica (1-3)', in: Studia Indogermanica Lodziensia, 4, 73-79.

Theodossiev, N., 2000, North-Western Thrace from the Fifth to the First Centuries BC (British Archaeological Reports, International Series, 859), Oxford.

Theodossiev, N., 2005, 'Celtic Settlement in the North-Western Thrace during the Late Fourth and Third Centuries BC: Some Historical and Archaeological Notes', in: Dobrzańska, H., Megaw, V., \& Poleska, P., Celts on the Margin: Studies in European Cultural Interaction VII Century $B C$ - I Century AD Dedicated to Zenon Woźniak, Kraków: Institute of Archaeology and Ethnology of the Polish Academy of Sciences.

Tikhanova, M. A., 1974, 'Celtic Problem in the Contemporary Archaeology' (= 'Kel'tskaya problema v sovremennoj arkheologii'. In Russian: “Кельтская проблема в современной археологии"), in: Yartseva, V. N, ed., Kel 'ty i kel 'tskiye yazyki, Moscow: Nauka, 5-14.

Todorović, J., 1974, Scordisci, istorija i kultura, Novi Sad - Beograd.

Todorović, J., 1980, 'The Autochthonous Component in the Celtic Culture in the Danube Region', in: Situla. Dissertationes Musei Nationalis Sloveniae, 20-21 (Knez, T., ed., Festschrift für Stane Gabrovec), Ljubljana.

Toporov, V. N., \& Trubachov, O. N., 1962, The Linguistic Analysis of Hydronyms of the Upper Dnieper (= Lingvisticheskij analiz gidronimov 
verkhnego podneprov'ja. In Russian: Лингвистический анализ гидронимов верхнего Поднепровья), Moscow.

Toporov, V. N., 1973, 'Regarding Cosmological Sources of Early Descriptions of Historical Character' (= 'O kosmologicheskikh istochnikakh ranneistoricheskikh opisanij'. In Russian: 'O космологических источниках раннеисторических описаний'), in: Trudy po znakovym sistemam, 6, Tartu: Tartu University, 106-150.

Toporov, V. N., 1988, 'Comparative-historical Commentary on Celtic Mythopoetic Parallels' (= 'Sravnitel'no-istoricheskij kommentarij k kel'tskim mifopoeticheskim parallelyam'. Published in Russian: 'Сравнительно-исторический комментарий к кельтским мифопоэтическим параллелям'), in: Yartseva, V.N., ed., Yazyk i kul'tura kel 'tov: materialy rabochego soveschaniya, Moscow: Nauka, 30-32.

Toporov, V. N., 1995, 'On Early Indian Charm Tradition' (= 'O drevneindijskoj zagovornoj traditsii'. In Russian: 'O древнеиндийской заговорной традиции'), in: Maliye formy fol 'klora: sbornik statej pamyati G. L. Permyakova, Moscow: Vostochnaya literatura.

Trubachov, O. N., 1967, 'On Slavic-Irish Lexical Relations' (= 'Iz slavyano-irlandskikh leksicheskikh otnoshenij'. Published in Russian: “Из славяно-ирландских лексических отношений”), in: Etymologiya, 3,81 .

Trubachov, O. N., 1983, 'Linguistics and the Ethnogenesis of the Slavs' (= 'Yazyko- znaniye i etnogenez slavyan. Drevniye slaviyane po dannym etimologii i onomastiki'. In Russian: 'Языкознание и этногенез славян. Древние славяне по данным этимологии и ономастики'. Славянское языкознание. IX Международный съезд славистов (Киев, 1983). Доклады советской делегащии), Moscow (= Voprosy yazykoznaniya, 4 (1982), 10-26).

Tsirkin, Y. B., 1974, 'Spanish Celts and the Process of their Romanisation' (='Ispanskiye kel'ty i ikh romanizatsiya'. In Russian: 'Испанские кельты и их романизация'), in: Yartseva, V.N, ed., Kel'ty i kel'tskiye yazyki, Moscow: Nauka, 22-31.

Vasmer, M., 1953, Russisches etymologisches Wörterbuch, 1, Heidelberg. 
Vasmer, M., 1971 = Bräuer, H., ed., Schriften zur slavischen Altertumskunde und Namenkunde, 1, Berlin.

Venclová, N., \& Kuna, M., eds., 1995, Whither Archaeology? Papers in Honour of Evzen Neustupny, Praha: Institute of Archaeology, Academy of Sciences of the Czech Republic.

Venclová, N., 1998, Mšecké Žehrovice in Bohemia. Archaeological background to a Celtic hero, $3^{r d}-2^{\text {nd }}$ cent. BC, Sceaux: Kronos.

Venclová, N., Bintliff, J., \& Kuna, M., eds., 2000, The Future of Surface Artefact Survey in Europe, Sheffield: Sheffield Academic Press.

Venclová, N., ed., 2001, (with Neustupny, E., Miroslavsky, M., Zakova, B., \& Valterova, P.), Vyroba a sidla v doble latenske Lodenice, Prague: Archeologický ústav AV ČR.

Veselovsky, A. N., 1873, 'Comparative Mythology and its Method' (review article) (= 'Sravnitel'naya mifologiya i eyo metod'. In Russian: 'Сравнительная мифология и ее метод'), in: Vestnik Evropy, 10, 637-680.

Veselovsky, A. N., 1913, 'The Poetics of the Subject' ('Poetika syuzhetov'. In Russian: 'Поэтика сюжетов (1897-1906)'. Собрание сочинений, 2, вып. 1), St. Petersburg.

Veselovsky, A. N., 1940, Historical Poetics (= Istoricheskaya poetika. Published in Russian: Историческая поэтика. Вступ. ст. и примеч. В. M. Жирмунского), Leningrad, (2 ${ }^{\text {nd }}$ ed. 1989, Moscow: Vysshaya shkola).

Wagner, H., 1969 (1970), 'The Origin of the Celts in the Light of Linguistic Geography', in: Transactions of the Philological Society, 1969 (1970), 203-250.

Wagner, H., 1971, Studies in the Origin of the Celts and of Early Celtic Civilisation. Belfast, Tübingen: (for the Belfast Institute of Irish Studies) Niemeyer.

Yartseva, V. N., 1940, 'Old Irish and other Celtic Languages in the System of the Indo-European Languages' (= 'Drevneirlandskij i drugiye kel'tskiye yazyki $\mathrm{v}$ sisteme indo-evropejskikh yazykov'. In Russian: 'Древнеирландский и другие кельтские языки в системе индоевропейских языков'), in: Ucheniye zapiski LGU, Philological series, 6. 
Yartseva, V. N., 1941, 'The Syntax of the Infinitive in Old Irish' (= 'Syntaksis infinitiva $\mathrm{v}$ drevneirlandskom'. In Russian: 'Синтакс инфинитива в древнеирландском'), in: Ucheniye zapiski $L G U$, Philological series, 5 .

Yartseva, V. N., ed., 1974, Celts and the Celtic Languages. Collection of Essays. (= Kel'ty i kel tskiye yasyki. Sbornik statej. In Russian: Keльты и кельтские языки. Сборник статей), Moscow: Nauka.

Yartseva, V. N., 1988, \& Falileyev, A. I. (with Shkunayev, S. V., \& Kalygin, V. P.), eds., 1993-2003, Celtic Languages and Culture (= Yazyk $i$ kul'tura kel'tov. In Russian: Язык и культура кельтов), $1^{\text {st }}-9^{\text {th }}$ Colloquia, Moscow - St. Petersburg.

Zhirmunsky, V. M., 1963, 'In memoriam Smirnov' (= 'Pamyati A. A. Smirnova'), in: Izvestiya Akademii Nauk SSSR, OLYa, 22, 1, 82-85.

\section{SUMMARY: \\ ШЭЙМАС МАК МАХУНА}

\section{ИСтоРия КЕЛЬтологии в России и СССР}

СЛЕДСТВИЕМ АКТИВНОЙ НАУЧНОЙ ДЕЯТЕЛЬНОСТИ СЛАВЯНСКИХ КЕЛЬТОЛОГОВ, НАМЕТИВШЕЙСЯ ЗАПОСЛЕДНИЕ ГОДЫ, СТАЛО УСИЛЕНИЕ ИНТЕР ЕСАЗАПАДНЫХ УЧЕНЫХ К ИХ ИССЛЕДОВАНИЯМ. БОЛЬШАЯ ЧАСТЬ РАБОТ СЛАВЯНСКИХ ИССЛЕДОВАТЕЛЕЙ ОПУБЛИКОВАНА НА СЛАВЯНСКИХ ЯЗЫКАХ И ПРАКТИЧЕСКИ НЕДОСТУПНА ЗАПАДНОМУ ЧИТАТЕЛЮ. ПО ЭТОЙ ПРИЧИНЕ ДОСТИЖЕНИЯ И ШИРОТА НАУЧНОГО КРУГОЗОРА РОССИЙСКИХ И ВОСТОЧНОЕВР ОПЕЙСКИХ КЕЛЬТОЛОГОВ НАХОДЯТСЯ, К СОЖАЛЕНИЮ, ЗА РАМКАМИ СОВРЕМЕННОЙ НАУЧНОЙ КЕЛЬТОЛОГИЧЕСКОЙ ПАРАДИГМЫ. В СТАТЬЕ ПРОСЛЕЖИВАЕТСЯ ИСТОР ИЯ И ОСНОВНЫЕ ВЕХИ РАЗВИТИЯ КЕЛЬТОЛОГИИ В РОССИИ И СССР. ОСОБ ОЕ ВНИМАНИЕ УДЕЛЕНО Р АБ ОТАМ Р УССКИХ КЕЛЬТОЛОГОВ, УПОМИНАЮТСЯ ЗНАКОВЫЕ Р АБ ОТЫ В ЭТОЙ ОБЛАСТИ ЧЕШСКИХ И ПОЛЬСКИХ КОЛЛЕГ. СТАТЬЯ ОХВАТЫВАЕТ ПРАКТИЧЕСКИ ВСЕ ПЕРИОДЫ СТАНОВЛЕНИЯ И РАЗВИТИЯ КЕЛЬТОЛОГИИ В РОССИИ, В НЕЙ ПЕРЕЧИСЛЯЮТСЯ И РЕЗЮМИРУЮТСЯ РАБОТЫ ОСНОВНЫХ ПРЕДСТАВИТЕЛЕЙ РУССКОЙ ШКОЛЫ В СФЕРЕ ИЗУЧЕНИЯ КЕЛЬТСКОЙ ЛИГВИСТИКИ, МИФОПОЭТИКИ, ЛИТЕР АТУРЫ, ИСТОР ИИ, А ТАКЖЕ КОМПАР АТИВИСТИКИ И СЕМИОТИКИ. 